NBER WORKING PAPER SERIES

\title{
SHOULD SIXTH GRADE BE IN ELEMENTARY OR MIDDLE SCHOOL? AN ANALYSIS OF GRADE CONFIGURATION AND STUDENT BEHAVIOR
}

\author{
Philip J. Cook \\ Robert MacCoun \\ Clara Muschkin \\ Jacob Vigdor \\ Working Paper 12471 \\ http://www.nber.org/papers/w12471
}

\author{
NATIONAL BUREAU OF ECONOMIC RESEARCH \\ 1050 Massachusetts Avenue \\ Cambridge, MA 02138
}

August 2006

\begin{abstract}
We are grateful to Josh Kinsler for exceptional research assistance, and to Katherine Conner, Camden Cook, Brad McMillan, and Allison Whitaker for their suggestions. This research is supported by grants from the National Institute on Drug Abuse and the William T. Grant Foundation. Any views expressed in this paper are the authors' alone and should not be associated with any affiliated institution. The views expressed herein are those of the author(s) and do not necessarily reflect the views of the National Bureau of Economic Research.

(C2006 by Philip J. Cook, Robert MacCoun, Clara Muschkin and Jacob Vigdor. All rights reserved. Short sections of text, not to exceed two paragraphs, may be quoted without explicit permission provided that full credit, including (C) notice, is given to the source.
\end{abstract}


Should Sixth Grade be in Elementary or Middle School? An Analysis of Grade Configuration and Student Behavior

Philip J. Cook, Robert MacCoun, Clara Muschkin and Jacob Vigdor

NBER Working Paper No. 12471

August 2006

JEL No. H52

\begin{abstract}
$\underline{\text { ABSTRACT }}$
Using administrative data on public school students in North Carolina, we find that sixth grade students attending middle schools are much more likely to be cited for discipline problems than those attending elementary school. That difference remains after adjusting for the socioeconomic and demographic characteristics of the students and their schools. Furthermore, the higher infraction rates recorded by sixth graders who are placed in middle school persist at least through ninth grade. A plausible explanation is that sixth graders are at an especially impressionable age; in middle school, the exposure to older peers and the relative freedom from supervision have deleterious consequences.

Philip J. Cook

Terry Sanford Institute of Public Policy

Box 90245

Duke University

Durham, NC 27708

and NBER

pcook@duke.edu

Robert J. MacCoun

Professor of Public Policy and Law

2607 Hearst Avenue

University of California

Berkeley, CA 94720

maccoun@berkeley.edu

Clara Muschkin

Center for Child and Family Policy

Duke University

Durham, NC 27708

muschkin@duke.edu

Jacob Vigdor

Terry Sanford Institute of Public Policy

Duke University

Durham, NC 27708

and NBER

jacob.vigdor@duke.edu
\end{abstract}




\section{INTRODUCTION}

What is the best grade configuration for schools that serve early adolescents? The predominant answer has changed over time. At the beginning of the twentieth century, school configuration in the United States began moving away from an eight-year primary and four-year secondary model, toward a definition of secondary education as beginning in the seventh grade. At that time and continuing through mid-century, middle schools known as "junior high" (grades 7-9 or 7-8) were the norm (Goldin 1999). This arrangement was intended to create a transitional period between the sheltered elementary school and the more demanding high school environment (Juvonen et al. 2004).

In recent decades there has been a marked shift away from junior high school, toward the middle school configuration of grades 6-8, or occasionally 5-8. In the early 1970s, less than onequarter of middle schools incorporated sixth grade: by 2000, three-quarters of all middle schools

enrolled sixth grade students (see Figure 1). North Carolina's public middle schools, which form the basis for the analysis that follows, have led the national trend of incorporating sixth grade. In the 1999-2000 school year, more than 90 percent of the state's 379 middle schools served grades 6-8 (McEwin, Greene and Jenkins 2001).

Figure 1

Why is the current generation of sixth graders attending middle school while preceding generations attended elementary school? The practical problem of dealing with swelling cohorts of students was a factor in promoting the shift in the 1970s, but there was also support from educators. In a survey of middle grade school administrators in 2000, 65 percent of respondents selected the 6-8 grade configuration as the "ideal" form of organization (Valentine et al 2002). Grade span re-configuration was part of a new paradigm for middle grade education that moved 
away from the "bridging" concept, toward focused consideration of the unique challenges faced by young teens (Juvonen et al 2004; National Middle School Association 1995). The debate over the proper configuration of grades has heated up again in recent years, with researchers and practitioners challenging the rationale of a separate middle school. One influential proposal has been to reduce the number of school transitions through a configuration that combines elementary and middle grades (Hough 1995; Juvonen et al 2004).

What has been for the most part lacking in this debate, and what we seek to provide, is direct evidence concerning what difference the grade configuration is likely to make for students. An important exception is the recent study by Kelly Bedard and Chau Do, which demonstrates using national data that moving to a middle-school configuration that includes sixth grade has the effect of reducing on-time high-school completion rates by approximately 1-3 percent (Bedard \& Do 2005). Our study provides evidence in general support of this finding by documenting one of the potential mechanisms - an increase in serious infractions.

\section{THE MIDDLE SCHOOL DIFFERENCE}

The middle school educational environment is different from the elementary school environment in several ways. A sixth grader in an elementary school will typically be assigned to one teacher and spend much of the day in that teacher's classroom with the same group of students. A sixth grader in middle school will typically be assigned to a team of teachers and move from classroom to classroom over the course of the school day, with somewhat different groups of students in each. Middle schools place greater emphasis on discipline and academic accomplishment (including greater use of between-classroom ability grouping), with less 
opportunity for close relationships to specific teachers (National Center for Education Statistics 2000; Mills 1998).

The decision of whether to locate sixth grade in middle school or keep it in elementary school should take account of the behavioral and academic consequences for the sixth graders themselves, as well as for the younger grades in elementary school, and the older grades in middle school. It is a difficult time of life at best. Between the ages of 10 and 14, students typically must adjust to puberty, as well as to changes in social relationships with peers, family, and authority figures (NMSA, 1996; Elias et. al, 1985; Eccles et al. et al., 1993; Rudolph et al., 2001). Research suggests that difficulties in coping with multiple transitions may underlie some of the negative effects that many students experience during the transition from elementary to middle school (Eccles et al. et al., 1993). These effects include a decline in motivation and a loss of self-esteem, particularly when the transition occurs at younger ages (Simmons and Blythe, 1987; Rudolph et al., 2001); decline in academic achievement (Alspaugh and Harting, 1995; Alspaugh, 2001); strains on interpersonal functioning (Barber and Olsen, 2004); and in the long term, increased risk of dropping out of school (Alspaugh, 1998; Rumberger, 1995).

Perhaps the most important difference is that a sixth grader in elementary school is among the oldest students in the school; a sixth grader in middle school is among the youngest, with daily exposure to older adolescents. In terms of both the developmental changes experienced by early adolescents, and the social and academic challenges that they face in the middle school environment, the influence of the peer group on behavior is particularly important. Research on adolescent delinquency suggests a developmental pattern of delinquent peer influence: the influence of peers on behavior already is significant in early adolescence, peaks during middle adolescence, and then begins to decline (Jang 1999). Peer influence may take a 
variety of forms, both direct and indirect. Direct influence may include bullying and initiation of fights, recruitment into delinquent gangs, an enhanced supply of drugs and alcohol, seduction and sexual importuning, an appreciative audience for rowdy behavior, companionship in truancy, and so forth. Indirect influence may occur through modeling illicit behavior (Reinke \& Walker 2006; Cook \& Goss 1995).

School characteristics have been shown to have contextual effects on the impact of peer influence. The influence of peers on individual substance use tends to be strongest in schools with higher rates of substance use (Cleveland and Wiebe, 2003). Other school context characteristics, including the size of the school population, racial composition, poverty levels, and levels of parental education also have been linked to peer influences on behavior (Teitler and Weiss, 2000; Ellickson et al., 2003; Hardy, Bukowski \& Sippola 2002).

\section{CONCEPTUAL FRAMEWORK}

In this study, we estimate the impact of school grade span on EOG test scores and on the prevalence and incidence of infractions by North Carolina public school students. Our main interest is on the infractions data; the data on EOG test scores, while of intrinsic interest, serve here as a check on the validity of our findings concerning behavior.

We presume that the behavior of student $i$ attending school $j$ in year $t$ can be measured with a latent variable $B_{i j t}$. When this variable exceeds some threshold level, which we normalize to zero, we observe an indicator variable $R_{i j t}$ indicating that a report of a negative behavioral outcome has been filed. Our conceptual model thus takes the form:

(1) $R_{i j t}=1$ if $B_{i j t}=\alpha_{0}+\alpha_{1} X_{i}+\alpha_{2} Z_{j}+\varepsilon_{i j t}>0$, 
where $X_{i}$ denotes a vector of student-level characteristics, and $Z_{j}$ identifies a vector of school characteristics. Our central hypothesis is that a particular school characteristic, the grade span, influences behavioral outcomes. The final term, $\varepsilon_{i j t}$, is a residual reflecting unobserved individual and school-level characteristics that determine whether a report is filed, plus any true idiosyncracies that operate in the report-generating process. There is a possibility that elements of $\varepsilon_{i j t}$ are correlated with observed school-level characteristics, in which case estimates of the coefficient vector $\alpha_{2}$ will be biased. We discuss this concern in more detail below.

Why might school grade composition affect student behavioral outcomes? Based on the discussion in the previous section, we can identify at least three potential causal mechanisms.

a) Social control effects. The overall rate of behavioral problems in a school can be influenced by various features of the school environment. The degree of freedom accorded the students, the capacity of the faculty and administration to monitor and control behavior, and the composition of the student body are all plausibly important. Elementary and middle schools tend to differ in all these dimensions. ${ }^{1}$

b) The transition effect. This mechanism suggests that student behavior will tend to deteriorate in the first year of exposure to a new school environment, particularly when that environment is less closely supervised than previously experienced, simply because it may take time to learn the rules and stay out of trouble in the new environment. This mechanism predicts a spike in behavioral problems for sixth grade students entering middle school, followed by a reversion to the usual age-based trajectory as the student

\footnotetext{
${ }^{1}$ It should be noted that among the environmental attributes that distinguish the two types of schools, not all are intrinsic to the form. For example, if sixth-grade teachers tend to prefer an elementary-school environment to a middle-school environment, then those who have a choice (including the most able teachers) will tend to concentrate in elementary schools. In that case the lower infraction rate in elementary schools would reflect the superior classroom-management ability of the teachers there.
} 
learns to meet the new expectations. Seventh grade students entering middle school for the first time should also exhibit a spike in behavioral problems.

c) Deviant peer-influence effects. Sixth graders might also display elevated levels of behavioral problems if they are unduly influenced by older peers who act in a similar fashion. This is a true "social" effect (Manski 1993): placement with a set of wellbehaved older peers would presumably lead to no increase in behavioral problems. Deviant contagion effects could possibly lead to permanently elevated levels of behavior problems, to the extent that such behaviors are habit-forming or self-reinforcing.

In addition to these hypothesized causal mechanisms, it is possible that any correlation between school grade span and the measured infraction rate reflects nonrandom sorting of students. Parents may choose where to live or whether to keep their children in the public schools based in part on the configuration of grades. That sort of selection process may influence the characteristics of the student body in ways not necessarily reflected in observed indicators.

Yet another possibility is that the likelihood that student misbehavior will be reported by school officials differs between elementary and middle school. In the context of our model, variation in standards of reporting across schools is one component of the error term $\square_{i j t}$. Thus a finding of higher rates of disciplinary infractions in these schools need not reflect any differences in actual student behavior. The finding may still be of interest, since at a minimum it tells us something about the likelihood that a student will acquire a "record."

In addition to the analysis of student infractions, we estimate standard linear models for the determination of EOG test scores, incorporating the same covariates as in equation (1). EOG tests are administered and scored the same for sixth graders whether they are in elementary 
or middle school. As a result, observed differences in performance are not an artifact of the measurement system.

\section{DATA AND MATCHING PROCEDURE}

Our analysis makes use of an administrative database covering all public schools and students in the state of North Carolina for a number of years. The data were provided by the North Carolina Education Research Data Center. The indicators of behavioral problems are derived from a statewide database of disciplinary infractions recorded during the 2000-2001 academic year. Each disciplinary report reflects a decision on the part of a school official (usually a teacher) of whether to "write up" a student for misbehaving, and then a decision on the part of the principal of whether to report to the state. (Schools are required to report incidents in the event that they result in the out-of-school suspension of one or more students, or if the offense is severe enough to warrant the contact of law enforcement officials, but reporting is otherwise left to the discretion of school officials.)

The districts in which sixth graders still attend elementary school in North Carolina are in small towns or rural areas, and are somewhat unrepresentative of the state school system as a whole in other respects as well. In our statistical work we used a matching procedure to select the middle schools for our sample; this procedure eliminated much of these differences. Our procedure had four steps. (1) Drop all middle schools located outside of small towns and rural areas. (2) Run a logit regression on the 344 remaining schools that included a sixth grade (both middle and elementary schools), to estimate the likelihood that that $6^{\text {th }}$ grade would be in middle school based on student characteristics and per pupil expenditures. (Table 1 reports the results.) (4) Compute probabilities for each of the 344 schools based on this estimated equation, and identify the maximum probability for an elementary school and the minimum probability for a 
middle school. (4) Select the matched sample, defined as those schools that had an estimated probability lying in between these extremes, thus ensuring a common support across the two groups.

Table 1 here

\section{ANALYSIS OF INFRACTION RATES}

The matched sample included 41,833 middle-school sixth graders of the 76,915 total, and almost all of the 5,320 elementary-school sixth graders. Table 2 reports summary statistics. All told, these students were responsible for 20,433 reported disciplinary infractions over the course of the school year. The summary statistics indicate a large difference in the average number of infractions per student between middle and elementary schools: There were 47 recorded infractions for every 100 sixth graders attending middle school, compared with only 16 per 100 in elementary schools. When infractions are classified by type, middle school students record over twice the rate for each category (Figure 2).

Table 2 here

Figure 2 here

The large differences in the infraction rate may be partly due to differences in characteristics of the student populations that remain despite the matching procedure. We used regression analysis in an attempt to adjust for these remaining differences. The sample for this analysis consists of sixth grade students in North Carolina in 2000-1 that are in our matched sample; the dependent variable indicates whether students appear in the infractions database. Control variables include indicators for the type of school attended, the number of students in sixth grade in that school, and school-level socioeconomic indicators, as well as individual characteristics including race and gender, parental education levels, and standardized EOG test 
scores from $5^{\text {th }}$ grade. The results confirm that attending middle school in sixth grade is associated with greatly elevated odds of an infraction. Our point estimates imply that other things equal, the odds of having at least one infraction in sixth grade are increased by a factor of 2.3 if in middle school; the odds of a violent infraction are increased by a factor of 2.0, and the odds of a drug infraction by a factor of $4.8 .^{2}$

Table 3 here

These regression results also reveal elevated prevalence rates for males, blacks, children of parents with less education, children in low-income families (who qualify for reduced price or free lunch), as well as children who are old for the grade or have low test scores in fifth grade. Note that each of these results emerges even controlling for all else.

These regressions include three explanatory variables characterizing the school rather than the individual student. The coefficients tend to be less precisely estimated, not surprising given that there is less variation. Still, it is interesting that the coefficient estimates on the size of the sixth grade are negligible, and that infraction rates are inversely related to the percentage of the school population that is poor (again, controlling for individual status in this respect).

\section{Behavior Before and After Sixth Grade}

It would be informative to follow these students over several years of schooling before and after sixth grade. Infractions in fourth and fifth grade would provide an individualized baseline on misbehavior. Infraction rates after sixth grade would allow a check on whether the elevated rate for the middle-school sixth graders is simply the result of problems resulting from a transition to a new school, or rather sustained over time. As it turns out, we only have

\footnotetext{
${ }^{2}$ We also estimated a negative binomial regression on the number of infractions. The results are qualitatively similar to the logit regression results for prevalence. The estimated coefficient on attending middle school in sixth grade is .913 , with a standard error or .222 .
} 
infractions data for the single academic year (2000-1), so it is not possible to follow the behavior of individual students over time. However, we are able to perform a pseudo-longitudinal analysis of behavior based on the fact that our database, while only including one year of infractions data, does include a number of years' worth of data on other aspects of each student's career. In particular we know what sort of school the students who are in fourth or fifth grade in 2000-1 are destined to spend sixth grade, and we know in what sort of school older students in that year did spend sixth grade. Using this information, we sort all students in grades 4-9 in 2000-1 into two groups, which we identify as 6Es and 6Ms. For example, a ninth grader is a "6M" if she spent her sixth grade in middle school; a fourth grader is a " $6 \mathrm{E}$ " if he subsequently attends sixth grade in an elementary school.

Figure 3 graphs the trajectories for the two groups with respect to probability of an infraction. These prevalence trajectories are computed for the same set of values for the regression covariates; the difference in trajectories reflects the proportional effect on the infraction probability estimated from the logistic regression, and the $95 \%$ confidence interval represents the uncertainty in that estimate. ${ }^{3}$ We see that in the baseline period, grades 4 and 5 , there is little difference between 6Es and 6Ms. A large gap opens up in sixth grade. The gap narrows a bit in seventh grade, when most of 6Es enter middle school, but is then sustained in eighth and ninth grades and remains statistically significant throughout. ${ }^{4}$ Other measures of misbehavior produce qualitatively similar results.

\footnotetext{
${ }^{3}$ The values assumed for the covariates generally refer to an average male student. Parental education is specified as high school graduate, and the race variable is 25 percent black (in line with the sample). Any changes in these or other covariates would only serve to shift both lines either up or down by the same proportional amount. The key is the significant difference across the groups holding all else equal.

${ }^{4}$ Figure 3 is based on regressions of the sort reported in Table 3 , for $4^{\text {th }}, 5^{\text {th }}, 7^{\text {th }}, 8^{\text {th }}$, and $9^{\text {th }}$ graders. The coefficient estimates on the indicator for whether they attended $6^{\text {th }}$ grade in middle
} 
Figure 3 here

These results do not rule out the logical possibility that the observed differences are partly due to differences in school reporting practices rather than in the actual behavior of the students. It seems reasonable to suppose that middle schools tend to be more formal and severe than elementary schools, which might explain the infraction gap between 6Es and 6Ms in sixth grade. However, it does not explain why that gap persists in seventh, eighth, and ninth grades, when all the students have moved on past elementary school. Hence we believe that the "infraction gap" reflects a "behavior gap."

\section{DISCUSSION}

The causal mechanisms that account for this difference in behavior cannot be identified directly from our data. Several differences between elementary and middle school may be relevant. In comparison with elementary school, middle school provides students more freedom and lacks the continuity and close connection provided by having one primary teacher. Most obviously, middle school brings sixth graders into routine contact with older adolescents who are likely to be a bad influence: older adolescents as a group are more rebellious and more involved in delinquency, sex, illicit drugs, and other activities that violate school rules. Of greatest concern is that the negative influence of middle school on sixth graders appears to linger through ninth grade.

Our results complement the recent finding that school systems that move sixth grade from elementary to middle school experience a 1 -3 percent decline in on-time graduation rates (Bedard \& Do 2005). We would predict that that shift would increase behavior problems, which

school and the corresponding standard errors from the logistic regressions for the probability of committing any infraction are as follows: for $4^{\text {th }}$ graders, $-0.242(0.195)$; for $5^{\text {th }}$ graders, -0.081 $(0.162)$; for $7^{\text {th }}$ graders, $0.438(0.158)$; for $8^{\text {th }}$ graders, $0.329(0.161)$; for $9^{\text {th }}$ graders, 0.376 (0.168). 
in some cases could lead to retention in grade or dropout. Together these findings cast serious doubt on the wisdom of the nationwide shift to the middle school format. 


\section{References}

Alspaugh, J.W. (1998) "The Relationship of School to School Transitions and School Size to High School Dropout Rates.” The High School Journal v.81 pp.154-60.

Alspaugh, J.W. (2001) "Achievement Loss Associated with the Transition to Middle School and High School.” The Journal of Educational Research v.92 pp.20-25.

Alspaugh, J.W. and R.D. Harting (1995) "Transition Effects of School Grade-Level Organization on Student Achievement." Journal of Research and Development in Education v.28 pp.145-49.

Barber, B.K. and J.A. Olsen. (2004) "Assessing the Transitions to Middle and High School." Journal of Adolescent Research v.19 pp.3-30.

Bedard, Kelly and Chau Do (2005) "Are middle schools more effective? The impact of school structure on student outcomes" The Journal of Human Resources 40(3), Summer: 660-682.

Cleveland, H.H. and R.P. Wiebe (2003) "The Moderation of Adolescent-to-Peer Similarity in Tobacco and Alcoholt Use by School Levels of Substance Use ." Child Development v.74 pp.279-91.

Cook, P.J. \& K.A. Goss (1995) “A Selective Review of the Social Contagion Literature” Duke University Working Paper.

Eccles, J.S., A. Wigfield, C. Midgley, D. Reuman, D. MacIver, and H. Feldlaufer. (1993) "Negative Effects of Traditional Middle Schools on Students' Motivation." The Elementary School Journal v.93 pp.553-74.

Elias, M.J., M. Gara and M. Ubriaco. (1985) “Sources of Stress and Support in Children's Transition to Middle School: An Empirical Analysis." Journal of Clinical Child Psychology v.14 pp.112-18.

Ellickson, P.L., D.F. McCaffrey, B. Ghosh-Dastidar, and D.L. Longshore. (2003) "New Inroads in Preventing Adolescent Drug Use: Results From a Large-Scale Trial of Project ALERT in Middle Schools." American Journal of Public Health v.93 pp.1830-36.

Goldin, Claudia (1999) “A brief history of education in the United States” NBER Historical Paper No. 119.

Hardy, C., W.M. Bukowski, and L.K. Sippola (2002) "Stability and Change in Peer Relationships During the Transition to Middle Level School." The Journal of Early Adolescence v. 22 pp.117-42. 
Hough, D. (1997) “A Bona Fide Middle School: Programs, Policy, Practice, and Grade Span Configurations, in J.L. Irvin (Ed.), What Current Research says to the Middle Level Practitioner (pp.285-294). Westerville, OH: National Middle School Association.

Jang, S.J. (1999) “Age-Varying Effects of Family, School and Peers on Delinquency: A Multilevel Modeling Test of Interactional Theory." Criminology v.37 pp.643-85.

Juvonen, J., V. Le, T. Kaganoff, C. Augustine and L. Constant. (2004) Focus on the Wonder Years: Challenges Facing the American Middle School. Santa Monica: RAND Corporation.

Manski, C.F. (1993) "Identification of Endogenous Social Effects: The Reflection Problem." Review of Economic Studies v.60 pp.531-42.

McEwin, K.C., M.W. Greene, and D.M. Jenkins (2001) Where do North Carolina's Middle Schools Stand in the $21^{\text {st }}$ Century? A Status Repot on Programs and Practices (Pinehurst, NC: NC Middle School Assn).

Mills, Rebecca (1998) "Grouping students for instruction in middle schools.” Eric Digest, Report: EDO-PS-98-4.

National Middle School Association (1995) This We Believe: Developmentally Responsive Middle Level Schools National Middle School Association, Columbus, Ohio.

National Middle School Association (2001) "Grade Configuration.” NMSA Research Summary \#1 (updated Sept. 2001).

North Carolina Department of Public Instruction (2004) "Last Best Chance 2004: Educating Young Adolescents in the Twenty-First Century. Middle Grades Task Force Report. North Carolina Department of Public Instruction and State Board of Education.

Reinke, W.M. \& H.M. Walker (2006) "Deviant peer effects in education" in K.A. Dodge, T.J. Dishion, \& J.E. Lansford, eds. (2006) Deviant Peer Influences in Programs for Youth. New York: The Guilford Press, 122-140.

Rudolph, K.D., S.F. Lambert, A.G. Clark, K.D. Kurlakowsky. (2001) "Negotiating the Transition to Middle School: The Role of Self-Regulatory Processes." Child Development v.72 pp.929-46.

Rumberger, R.W. (1995) "Dropping Out of Middle School: A Multilevel Analysis of Students and Schools." American Educational Research Journal v.32 pp.583-625.

Simmons, R.O. and D.A. Blythe (1987) Moving into Adolescence. New York: Aldin De Gruyter.

Teitler, J. and C. Weiss. (2000) "Effects of Neighborhood and School Environments on Transitions to First Sexual Intercourse." Sociology of Education v.73 pp.112-32. 
Valentine, J.W., D. Clark, D. Hackmann, and V. Petzo. (2002) Leadership in middle level schools, volume I: A national study of middle level leaders and school principals. Reston, VA: National Association of Secondary School Principals. 
Table 1

Logistic regression results for matching procedure*

Dependent Var: Indicator for 6th grade in Middle School

\begin{tabular}{lrc} 
& Coeff. & SE \\
Average Math Score & 0.461 & 0.686 \\
\% Black & $\mathbf{3 . 3 4 3}$ & 1.094 \\
\% Hispanic & $\mathbf{9 . 1 4 6}$ & 3.442 \\
\% Parents without HS diploma & -2.454 & 1.993 \\
\% Students receiving free or reduced lunch & $\mathbf{- 3 . 4 1 8}$ & 1.554 \\
\% of students old for grade & $\mathbf{9 . 2 3 5}$ & 2.350 \\
\% of students learning disabled & -0.101 & 4.001 \\
Per Pupil Expenditure - Local (thousands) & $\mathbf{0 . 0 0 2}$ & 0.001 \\
Per Pupil Expenditure - Federal (thousands) & 0.001 & 0.001 \\
Constant & $\mathbf{- 3 . 0 2 3}$ & 1.259 \\
\hline N & 344 & \\
Pseudo R-sq & 0.226 &
\end{tabular}

Note: bold font indicates statistical significantly different

from zero, $p<.05$.

\begin{abstract}
*The sample includes schools containing 6th grade students that can be categorized as either an elementary or middle school. The regressors are characteristics of the 6th grade students only. Because all of the elementary schools containing 6th grade are located in small towns or in rural areas, only middle schools from those locales are included in the sample.
\end{abstract}


Table 2 Summary Statistics for $6^{\text {th }}$ Graders, 2000/2001, North Carolina Public Schools in Matched Sample

\begin{tabular}{|l|c|c|}
\hline & Middle School Students & Elementary Students \\
\hline Number of students & 41,833 & 5,109 \\
\hline Total infractions & 19,623 & 810 \\
Infractions/student & 0.47 & 0.16 \\
\hline \% Male & 50.91 & 50.75 \\
\hline \% White & 67.87 & 67.57 \\
\% Black & 24.79 & 23.39 \\
\% Hispanic & 3.95 & 3.07 \\
\% Asian & 1.08 & 2.11 \\
\% Other & 2.31 & 3.86 \\
\hline Parents' education: & & \\
\% High School Grad & 46.37 & 48.18 \\
\% 2-year college grad & 18.84 & 19.71 \\
\% 4-year college grad & 22.25 & 19.31 \\
\hline \% Reduced/Free Lunch & 43.26 & 48.55 \\
\hline Avg. Math EOG Score, th $_{\text {th }}$ Reading EOG Score & 159.58 & 159.07 \\
Avg. & 154.98 \\
\hline School level variables & 155.16 & \\
\% Reduced/Free lunch & & 44.70 \\
\% Black & 40.35 & 24.01 \\
Number of Grades & 25.03 & 6.26 \\
Number of 6 ${ }^{\text {th }}$ Graders & 2.99 & 119.24 \\
\hline
\end{tabular}


Table 3.

Logistic regression results on the likelihood of an infraction during the school year, Matched Sample, North Carolina $6^{\text {th }}$ Graders, 2000/2001

\begin{tabular}{|c|c|c|c|}
\hline & Any Infraction & Violent Infraction & Drug Infraction \\
\hline In middle school & $\begin{array}{l}\mathbf{0 . 8 3 5} \\
(.215)\end{array}$ & $\begin{array}{c}\mathbf{7 0 2} \\
(.220)\end{array}$ & $\begin{array}{l}\mathbf{1 . 5 6 0} \\
(.775)\end{array}$ \\
\hline Male & $\begin{array}{l}\mathbf{1 . 0 9 0} \\
(.041)\end{array}$ & $\begin{array}{l}\mathbf{1 . 1 9 5} \\
(.054)\end{array}$ & $\begin{array}{l}\mathbf{1 . 0 9 6} \\
(.299)\end{array}$ \\
\hline Race (White omitted) & & & \\
\hline Black & $\begin{array}{l}\mathbf{0 . 6 0 2} \\
(.052)\end{array}$ & $\begin{array}{l}\mathbf{0 . 6 1 4} \\
(.072)\end{array}$ & $\begin{array}{r}\mathbf{- 0 . 8 8 2} \\
(.369)\end{array}$ \\
\hline Hispanic & $\begin{array}{r}\mathbf{- 0 . 3 3 9} \\
(.105)\end{array}$ & $\begin{array}{r}\mathbf{- 0 . 4 7 0} \\
(.132)\end{array}$ & $\begin{array}{l}-0.240 \\
(.583)\end{array}$ \\
\hline Asian & $\begin{array}{l}\mathbf{- 1 . 3 7 0} \\
(.266)\end{array}$ & $\begin{array}{l}\mathbf{- 1 . 1 7 8} \\
(.323)\end{array}$ & \\
\hline Other & $\begin{array}{l}-0.194 \\
(.132)\end{array}$ & $\begin{array}{l}-0.176 \\
(.164)\end{array}$ & $\begin{array}{l}0.037 \\
(.481)\end{array}$ \\
\hline $\begin{array}{l}\text { Parents' education } \\
\text { (High school grad } \\
\text { omitted): }\end{array}$ & & & \\
\hline High School dropout & $\begin{array}{l}\mathbf{0 . 3 4 9} \\
(.045)\end{array}$ & $\begin{array}{l}\mathbf{0 . 3 5 0} \\
(.053)\end{array}$ & $\begin{array}{l}\mathbf{0 . 7 3 3} \\
(.275)\end{array}$ \\
\hline Trade school & $\begin{array}{l}-0.111 \\
(.081)\end{array}$ & $\begin{array}{l}-0.185 \\
(.099)\end{array}$ & $\begin{array}{l}-1.138 \\
(1.018)\end{array}$ \\
\hline Community college & $\begin{array}{l}\mathbf{- 0 . 1 5 4} \\
(.056)\end{array}$ & $\begin{array}{l}-0.132 \\
(.071)\end{array}$ & $\begin{array}{l}-0.394 \\
(.466)\end{array}$ \\
\hline 4-year college & $\begin{array}{l}\mathbf{- 0 . 5 6 1} \\
(.067)\end{array}$ & $\begin{array}{r}\mathbf{- 0 . 6 9 2} \\
(.082)\end{array}$ & $\begin{array}{l}-0.738 \\
(.395)\end{array}$ \\
\hline Graduate degree & $\begin{array}{r}\mathbf{- 0 . 7 3 0} \\
(.145)\end{array}$ & $\begin{array}{r}\mathbf{- 0 . 9 2 5} \\
(.178)\end{array}$ & \\
\hline Reduced/Free Lunch & $\begin{array}{l}\mathbf{0 . 3 7 9} \\
(.045)\end{array}$ & $\begin{array}{l}\mathbf{0 . 3 4 4} \\
(.051)\end{array}$ & $\begin{array}{l}\mathbf{0 . 6 4 6} \\
(.239)\end{array}$ \\
\hline Old for grade & $\begin{array}{l}\mathbf{0 . 3 5 1} \\
(.044)\end{array}$ & $\begin{array}{l}\mathbf{0 . 3 3 4} \\
(.054)\end{array}$ & $\begin{array}{l}\mathbf{0 . 4 1 7} \\
(.194)\end{array}$ \\
\hline Math EOG Score, $5^{\text {th }}$ & $\begin{aligned} \mathbf{- 0 . 2 1 4} \\
(.030)\end{aligned}$ & $\begin{array}{l}\mathbf{- 0 . 2 2 0} \\
(.037)\end{array}$ & $\begin{array}{l}\mathbf{- 0 . 3 8 1} \\
(.160)\end{array}$ \\
\hline $\begin{array}{l}\text { Reading EOG Score, } \\
5^{\text {th }}\end{array}$ & $\begin{array}{l}\mathbf{- 0 . 1 9 3} \\
(.029)\end{array}$ & $\begin{array}{r}\mathbf{- 0 . 1 4 2} \\
(.034)\end{array}$ & $\begin{array}{l}\mathbf{- 0 . 0 9 6} \\
(.136)\end{array}$ \\
\hline $\begin{array}{l}\text { School level variables } \\
\% \text { Reduced/Free }\end{array}$ & & & \\
\hline lunch & $\begin{array}{l}-1.117 \\
(.580)\end{array}$ & $\begin{array}{l}-0.980 \\
(.507)\end{array}$ & $\begin{array}{l}-1.260 \\
(1.608)\end{array}$ \\
\hline$\%$ Black & $\begin{array}{l}0.521 \\
(.397)\end{array}$ & $\begin{array}{l}0.452 \\
(.358)\end{array}$ & $\begin{array}{l}-1.124 \\
(1.677)\end{array}$ \\
\hline Size of $6^{\text {th }}$ grade & $\begin{array}{l}-.037 \\
(.116)\end{array}$ & $\begin{array}{l}-.027 \\
(.106)\end{array}$ & $\begin{array}{c}-.23 \\
(.245)\end{array}$ \\
\hline
\end{tabular}




\begin{tabular}{|l|c|c|c|}
\hline Constant & $\mathbf{- 3 . 0 3 5}$ & $\mathbf{- 3 . 9 1 8}$ & $\mathbf{- 7 . 6 5 6}$ \\
& $(.364)$ & $(.338)$ & $(.987)$ \\
\hline Sample size & 46,942 & 46,942 & 46,942 \\
\hline
\end{tabular}

Note: bold font indicates statistical significantly different from zero, $p<.05$. 
Figure 1

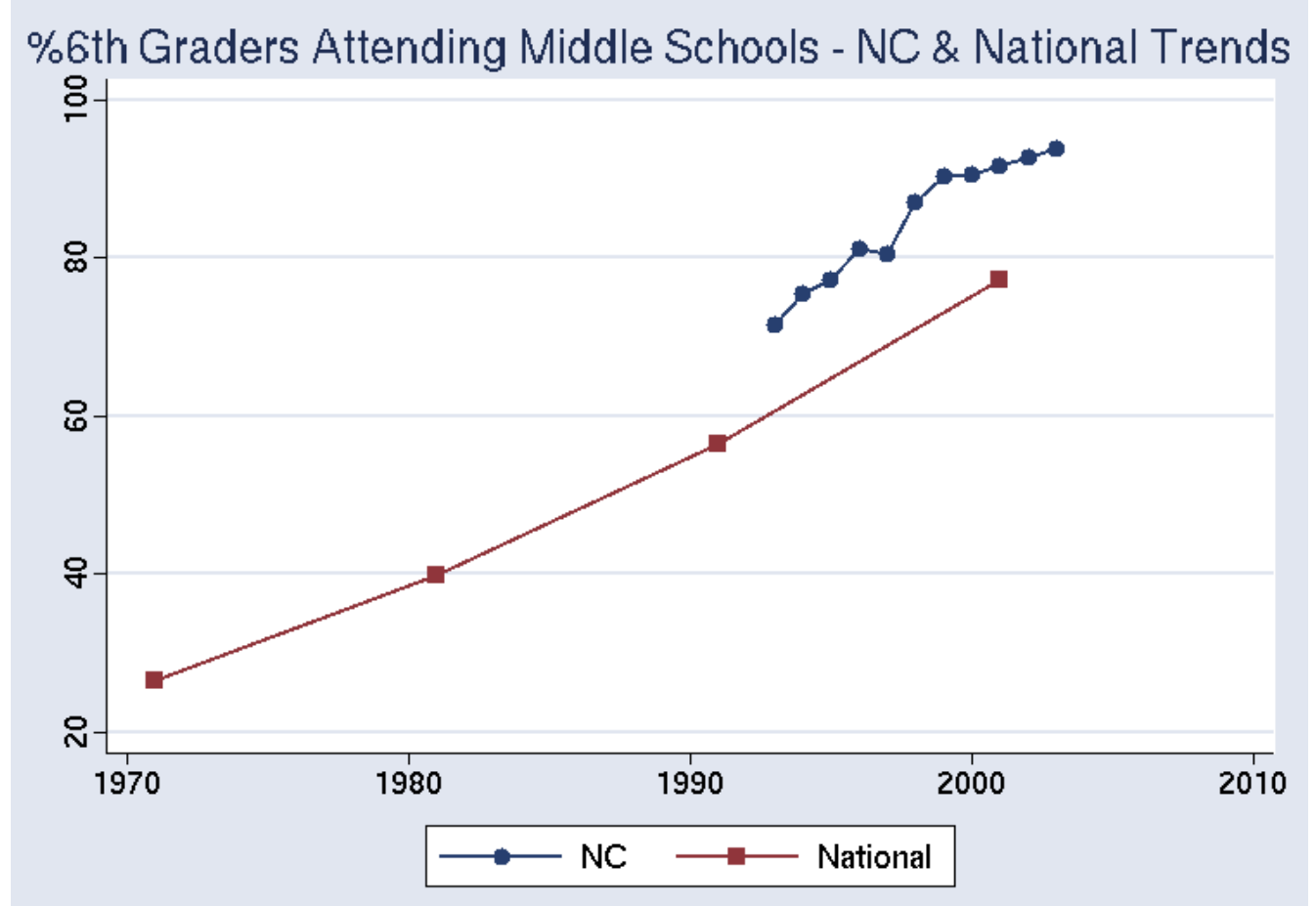


Figure 2. The fraction of sixth graders in North Carolina public schools who received at least one infraction of the specified type in 2000/2001.

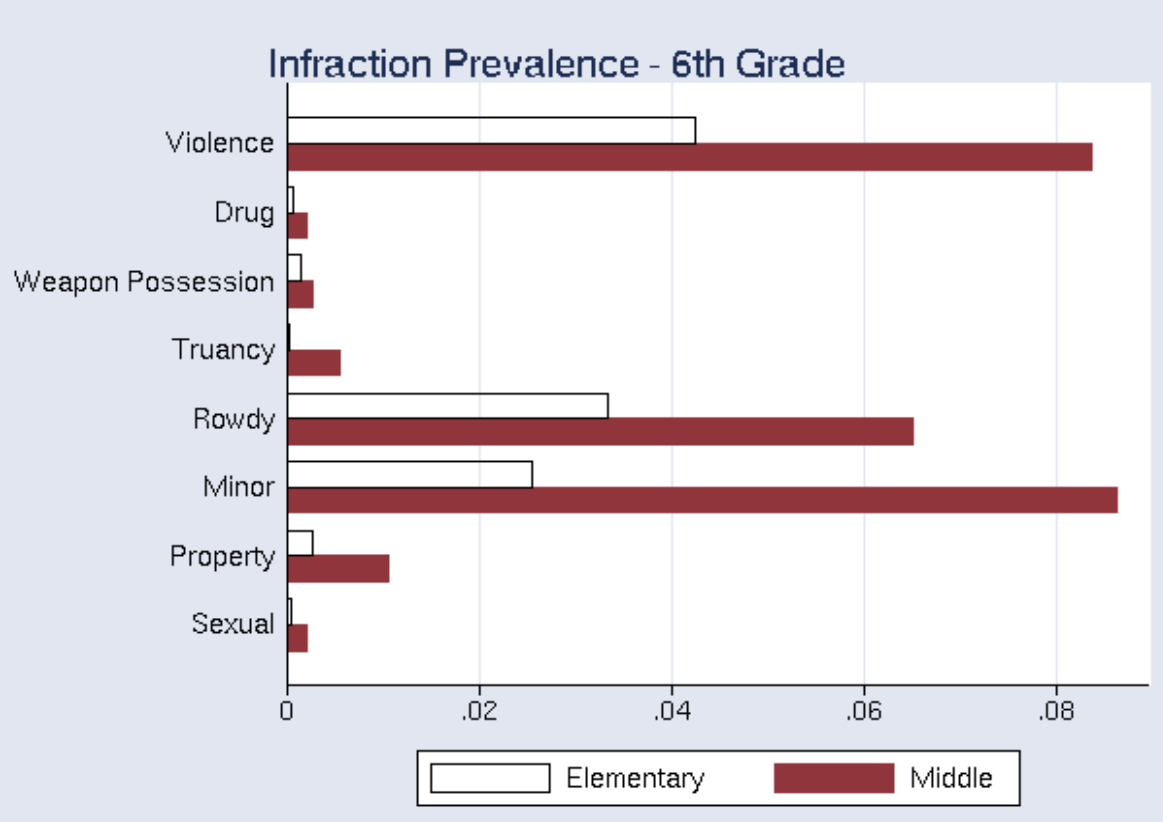


Figure 3. The prevalence of infractions for students who attend $6^{\text {th }}$ grade in elementary school, compared with the adjusted prevalence of infractions for students who attend $6^{\text {th }}$ grade in middle school. The adjustment is accomplished by restricting the sample to middle schools that are similar to the elementary schools, and then by logistic regression on individual and school characteristics.

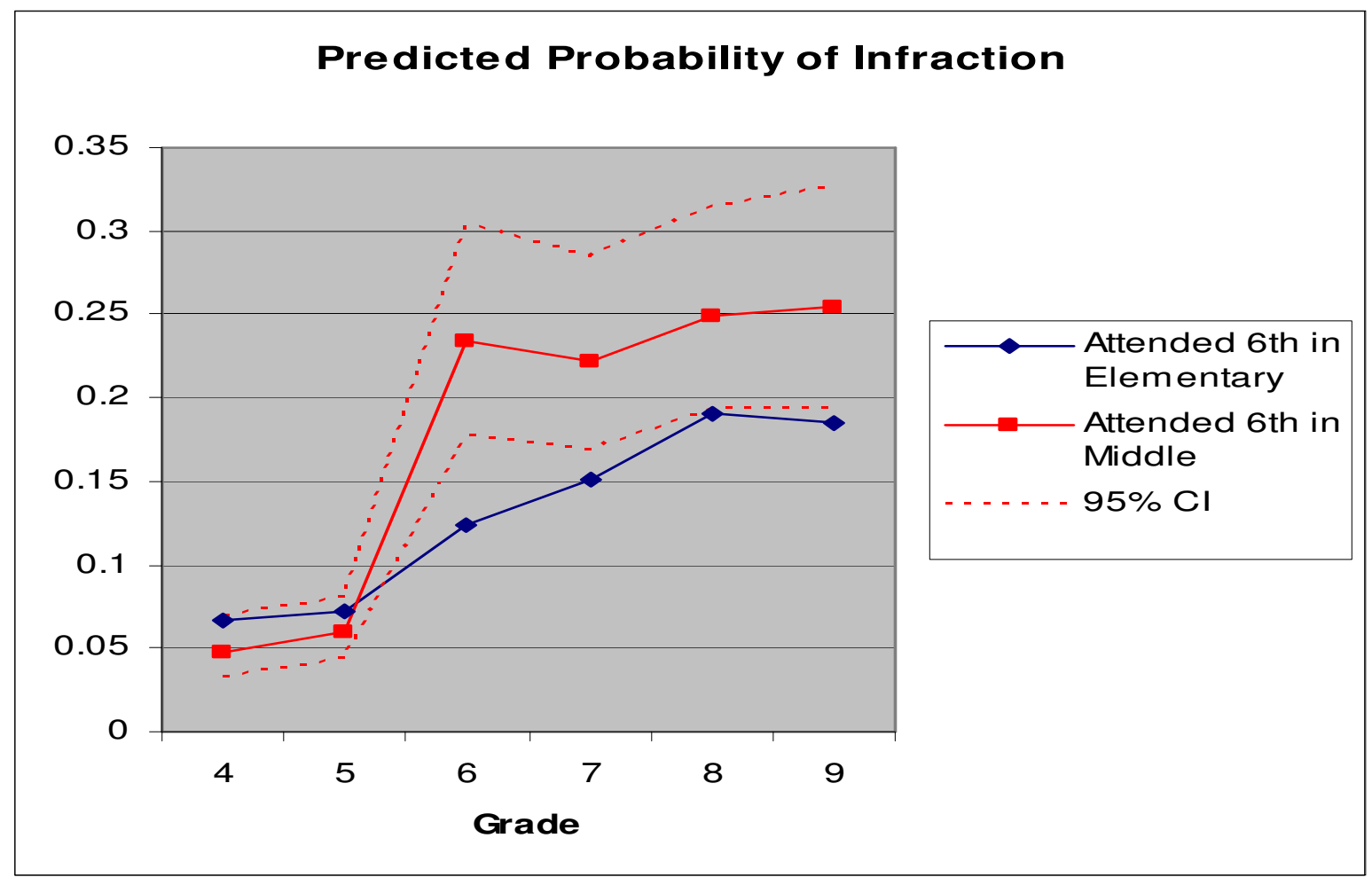

